\title{
Iceland: a window on North-Atlantic divergent plate tectonics and geologic processes
}

1 Nordic Volcanological Center, Institute of Earth Sciences, University of Iceland. E-mail: $f_{s} @$ hi.is.

2 Iceland Geosurvey, Grensásvegur 9, 108 Reykjavík, Iceland.

Opening of the North Atlantic about 60 million years ago was associated with massive basaltic volcanism, now found on both sides of the Atlantic Ocean. Divergence of the North American and Eurasian plates since then has formed the ocean floor in the North Atlantic, with the Mid-Atlantic Ridge marking the present day plate boundary. Iceland is the only large sub-aerial portion of the ridge. These unique conditions provide a "window" on divergent plate tectonics and related geologic processes, some of the main features of which are described and explained in this paper. The geological record in Iceland reaches back into late Tertiary and is particularly notable for the interplay of rift-volcanism and glaciation during the last three million years of rapid climate change.

\section{Introduction}

The location of Iceland on the Mid-Atlantic Ridge provides unique opportunities for studying on-going geological processes related to sea-floor spreading and plume upwelling. This paper summarizes the main features of Iceland's geology and crustal structure, and compares them with geophysical observations of on-going crustal movements. Extensive studies of present day crustal movements have been conducted in Iceland using a variety of techniques, including levelling, precise geodetic measurements with the Global Positioning System, and interferometric analysis of satellite radar images (Sigmundsson, 2006). The volcanic activity is rather unique when compared to other areas above sea level, as it is more akin to activity on mid-oceanic ridges below sea level. The volcanoes of Iceland occur both within the main rift zones and also in off-rift flank zones where little or no spreading occurs. Many of Iceland's volcanoes are presently covered by ice, causing spectacular ice-volcano interaction. Rarely does such diverse volcanic activity as in Iceland occur in any one area on Earth. A more comprehensive treatment of Iceland's geology and tectonics is to be found in a special issue of Jökull, the Icelandic Journal of Earth Sciences (see e.g., Einarsson, in press, and other articles in the same issue).

\section{Mantle plume-mid-ocean ridge interaction}

The magnetic field in the Iceland region has been revealed in detail by extensive marine magnetic surveys, as well as aeromagnetic surveys conducted over Iceland (e.g., Kristjánsson et al., 1989; Jonsson et al., 1991). The geomagnetic field anomalies over Iceland are irregular, but parallel to the Mid-Atlantic Ridge to the south and north. Spreading has been restricted to a single axis south of Iceland, but a rift relocation has occurred north of Iceland. Spreading across the currently active Kolbeinsey Ridge began about 24 million years ago, but a prominent extinct ridge, the Aegir Ridge in the Norway basin, was active before. Magnetic anomalies are clear on each side of the Kolbeinsey Ridge (Figure 1), revealing a full spreading rate of about $2 \mathrm{~cm} / \mathrm{yr}$ for the last 12 million years (Vogt et al., 1980). The spreading rate north of Iceland inferred from magnetic anomalies is one of the 277 globally distributed spreading rates used by DeMets et al.

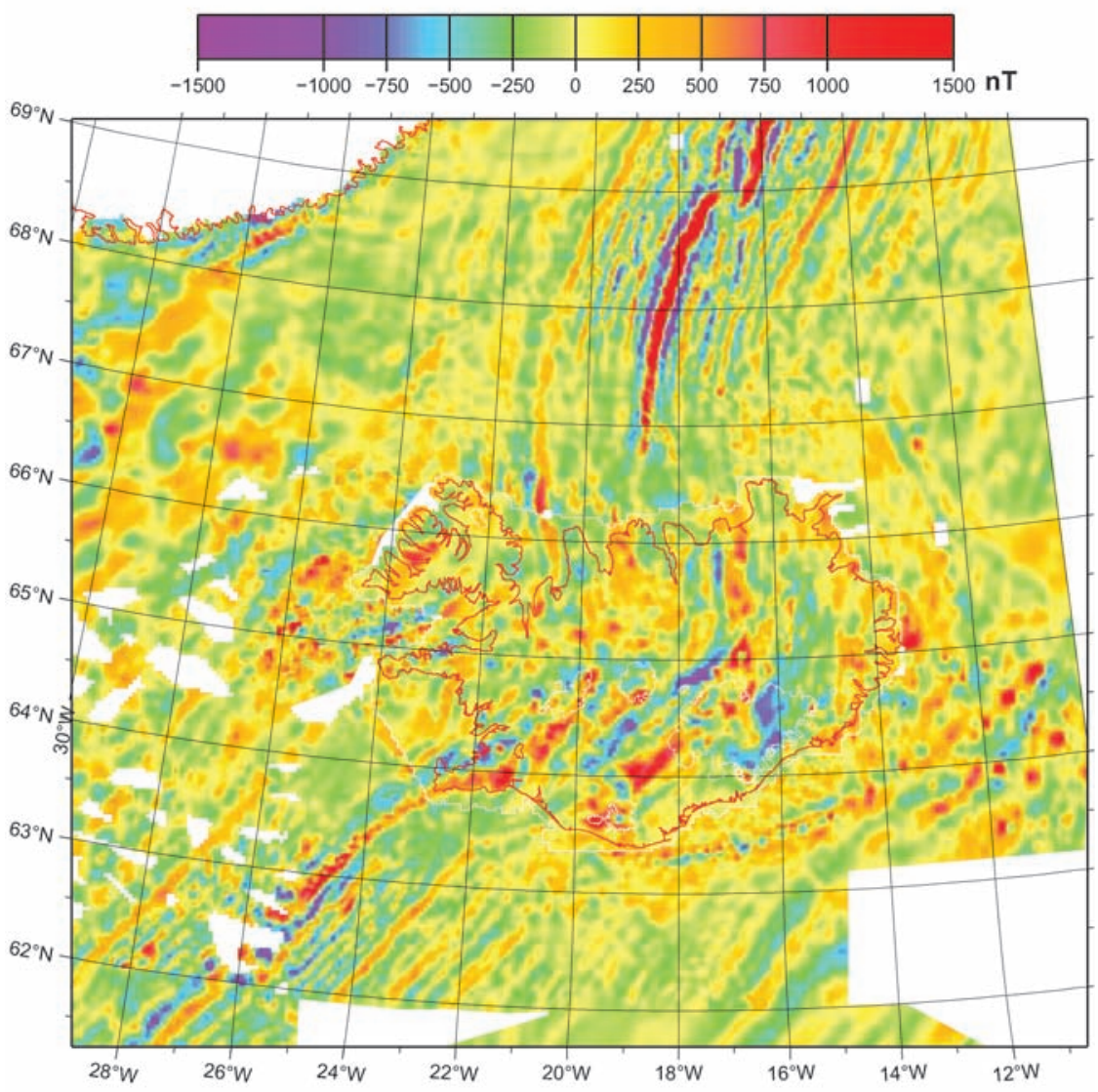

Figure 1 Total magnetic field anomaly map of Iceland and the North Atlantic. After Eysteinsson and Gunnarsson (1995). 
(1994) to constrain the NUVEL-1 and NUVEL-1A plate motion model. According to the NUVEL-1A model, the inferred full spreading velocity in central Iceland $\left(64.5^{\circ} \mathrm{N}, 18^{\circ} \mathrm{W}\right)$ is $18.3 \mathrm{~mm} / \mathrm{yr}$ in direction $\mathrm{N} 105^{\circ} \mathrm{E}$. This estimate represents an average over a few million years time interval. The variation in spreading rate across Iceland, due to different distances from the pole of rotation, is less than $2 \mathrm{~mm} / \mathrm{yr}$.

An estimate of spreading rates, on a completely different timescale (years) can be inferred from precise geodetic measurements. Geodetic stations are needed on both sides of the plate boundary deformation zone, the central part of which is marked by extensive faulting and fissuring (Figure 2). The data have to be interpreted with care, as geodetic stations within plate boundary deformation zones in Iceland show spatial and temporal variation relating to various local processes. Only stations outside the main plate boundary deformation zone can directly give the divergence rate. A network of continuous GPS stations in Iceland (Geirsson et al., 2006) contains some stations outside these zones. Stations with the longest observation span are the REYK station in Reykjavík on the North American plate, and the HOFN station located in SE-Iceland on the Eurasian plate (Figure 3 ). The relative velocity between these two stations in 1999-2004 inferred by Geirsson et al. (2006) is $21.9 \mathrm{~mm} / \mathrm{yr}$ in direction $\mathrm{N} 102^{\circ} \mathrm{E}$, slightly larger than the NUVEL$1 \mathrm{~A}$ and REVEL velocities. The rates may reflect minor contributions from local processes, such as on-going glacio-isostatic movements (Pagli et al., 2007). The observed relative velocity between the REYK and HOFN stations allows, however, the conclusion that essentially all of the spreading across the Mid-Atlantic Ridge is accommodated within the width of Iceland.

The crustal structure of Iceland is fundamentally different from that of the adjacent Mid-Atlantic Ridge, being influenced by excessive melting attributed to the Iceland mantle plume. Seismic and gravity studies as well as mantle melting models provide insights. Recent seismic data argue for a thick relatively cold crust under Iceland, with crustal thickness increasing from c. $15 \mathrm{~km}$ in the coastal areas towards c. $40 \mathrm{~km}$ under central Iceland, with clear seismic reflections originating from a Moho. A fully three-dimensional study of the crustal structure of Iceland by Allen et al. (2002), based on a combination of surface wave and body wave data, as well as constraints from gravity data, gives a map of crustal thickness (Figure 4). There is little contrast in density between crust and mantle (Gudmundsson, 2003), and the large crustal thickness is consistent with high melt production in a mantle plume under Iceland. Various geochemical studies have been conducted to infer the style of mantle melting under Iceland, and the relation of melt generation to crustal structure and thickness (e.g., Maclennan et al., 2001a and b).

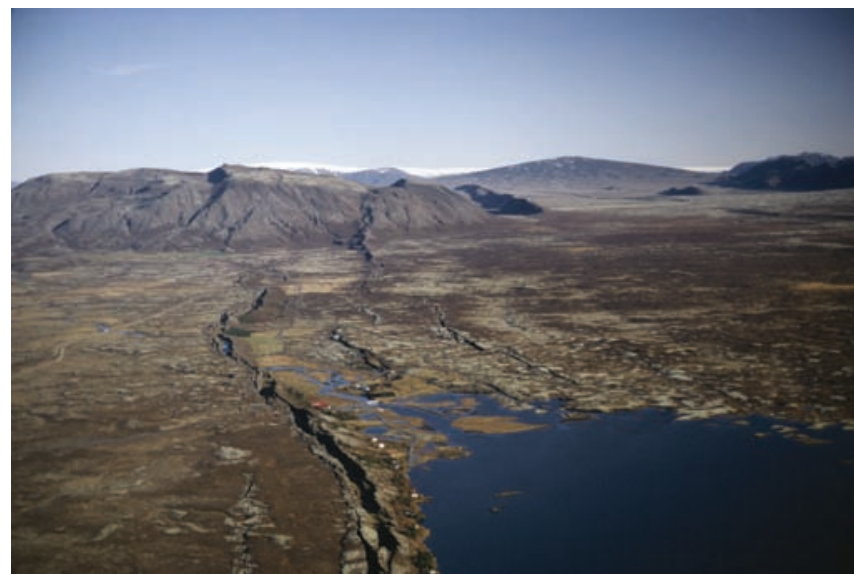

Figure 2 View from the plate boundary in Iceland at the Thingvellir site north of Lake Thingvallavatn in the western volcanic zone of Iceland. The photograph shows normal faults and tension fractures in a postglacial lava field, extending into a hyaloclastite mountain. To the right in the far distance is the Skjaldbreidur lava shield (Photo: Ágúst Gudmundsson, GEOICE).

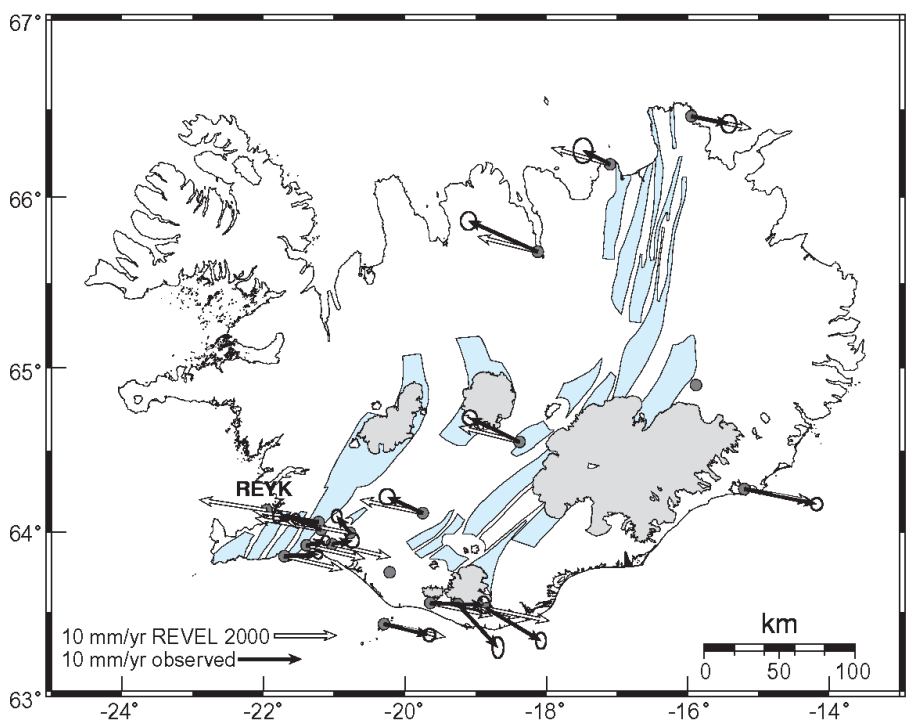

Figure 3 Velocities of continuous GPS stations in Iceland 1999-2004 (black arrows), assuming the REYK station moves at 10.5 $\mathrm{mm} / \mathrm{yr}$ towards east and $1.6 \mathrm{~mm} / \mathrm{yr}$ towards north. Confidence limits at the $2 \sigma$ level are shown. The white arrows are velocities from the REVEL plate motion model (Sella et al., 2002), assuming stations on the North American plate move with a velocity equal to half of the inferred spreading across Iceland, and stations on the Eurasian plate move equally, but in opposite direction (movements relative to the central axis of the plate boundary). After Geirsson et al. (2006).

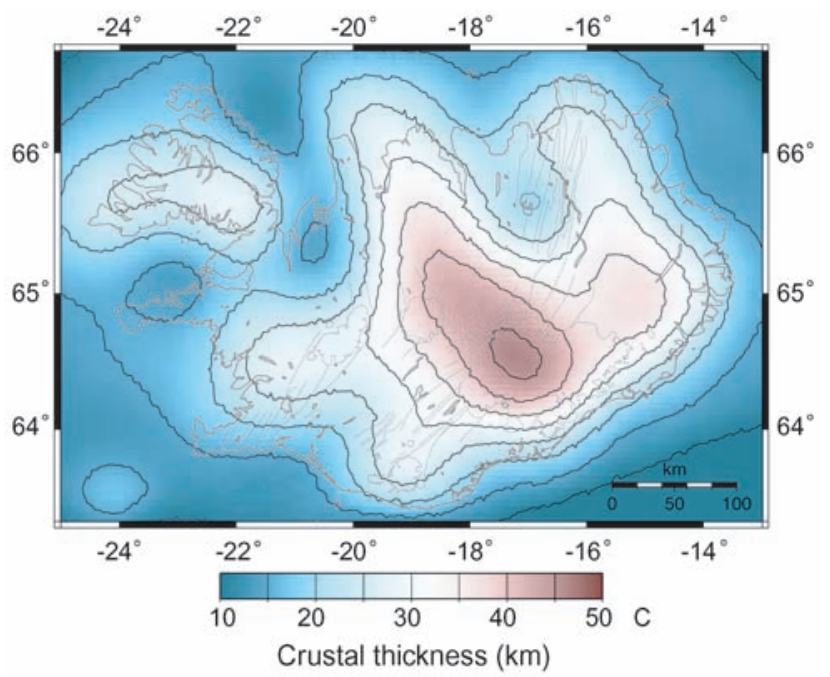

Figure 4 Crustal thickness model ICECRTb from Allen et al. (2002).

\section{Geology}

Rocks in Iceland are divided into four stratigraphic series based on climatic conditions at the time of formation, paleomagnetic field reversals, and radiometric age data. This division is somewhat modified from that used elsewhere and is shown on the geologic map of Iceland (Figure 5). An overview of the geology is given e.g. Saemundsson $(1974,1978,1979,1986)$ and Sigmundsson (2007). Iceland is mostly made up of basalts. They cover about $92 \%$ of the surface area of postglacial volcanic zones, whereas $4 \%$ are basaltic andesites, $1 \%$ are andesites, and $3 \%$ are dacite-rhyolites. The detailed geochemistry of volcanic rocks is complicated by the underlying mantle plume and rift relocations when new rift segments form in older crust (e.g., Oskarsson et al., 1985). The basic volcanotec- 


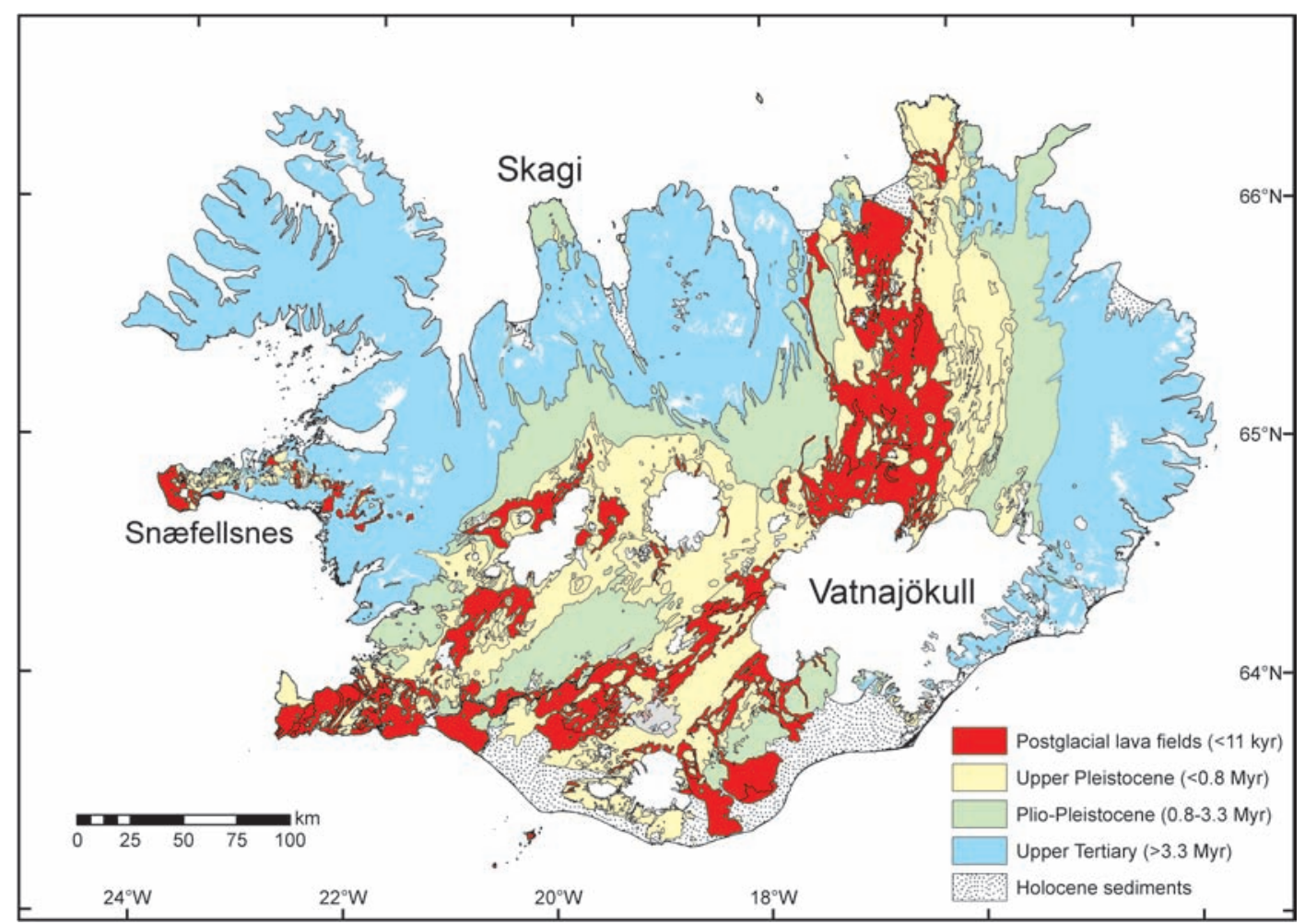

Figure 5 Geologic map of Iceland. Modified from Jóhannesson and Scemundsson (1998).

tonic units forming the upper extrusive part of the crust are elongate volcanic systems. Each is active for a period of about 1 million years, during which a central volcano and an associated fissure/dike swarm is formed.

Rocks older than 3.3 Ma make up the Tertiary series covering about half of Iceland. It occurs in eastern, western and northern Iceland, with ages increasing with distance from extinct and active spreading zones. The oldest rocks, $14-15 \mathrm{Ma}$, are found in western and eastern Iceland, whereas rocks in north Iceland are up to $12 \mathrm{Ma}$. The Tertiary rocks formed prior to extensive glaciations on Iceland, so glacial deposits and subglacial volcanic products are rare. Most of the Tertiary series consists of a regular basaltic lava pile of slightly variable lithology. Subaerially erupted tholeiitic lavas about 5-15 m thick, separated by minor clastic interbeds of volcanic origin, form the bulk of the Tertiary lava pile. Within this lava pile, a vertical thickness of $1 \mathrm{~km}$ spans about 1 million years, on average. The corresponding lava deposition rate was low; about one lava flow per 10000 years. However, these rates vary over a range from about c. $0.4-2 \mathrm{~km}$ per million years and only apply to areas outside of the volcanic centres. The interbeds between lava layers in the lava pile are, most commonly, thin layers of red or red-brown clayey or tuffaceous material. Thicker sedimentary beds commonly separate the main volcanotectonic units (Saemundsson, 1979). An integral part of the Tertiary lava pile are central volcanic complexes (central volcanoes). Where exhumed by erosion, they form structural irregularities with typically thin basaltic lava flows dominating and also silicic rocks as thick flows or pyroclastic sheets. The central part is characterized by collapse, clustering of intrusions and high alteration. Dike swarms, tens of $\mathrm{km}$ in length, are centred on the central volcanic complexes. The deepest level of erosion of about $2 \mathrm{~km}$ in SE-Iceland exposes a regional laumontite alteration zone and a local chlorite epidote cupola associated with the intrusive complexes. The eroded central volcanoes are analogues to the currently active volcanic centres in the neovolcanic zones, the dike swarms being the subsurface expression of fissure swarms. A characteristic feature of the Tertiary series is a regional tilting of the lava pile towards the volcanic zones in which they originated. The dips vary from near zero at the highest exposed levels to about $5-10^{\circ}$ at sea level, the result of gradual loading from volcanic production (Figure 6). Anticlinal structures have formed in association with rift relocation, with lava loading occurring in two successively active rift zones.

The beginning of the Plio-Pleistocene in Iceland is somewhat arbitrarily set at the end of the Mammoth paleomagnetic event at 3.3 Ma. About this time, climate cooled with the onset of frequent glaciations. The change was not abrupt, as deposits of glacial origin, among them hyaloclastite ridges typical of subglacial fissure eruptions, are found in the Tertiary lava pile back to about 7 million years in southeastern Iceland. However, the changes at c. $3.3 \mathrm{Ma}$ were drastic. Tuffs and volcanogenic sediments amount to only some 5\% of the volume of the Tertiary series, whereas subglacial volcanics and glacially derived detrital beds gain in volume in later formations and may exceed $50 \%$ of its volume in the Quaternary. Rocks formed during the Plio-Pleistocene include extensive fluvioglacial and morainic deposits as well as hyaloclastites. The structure of this rock series differs from the more uniform Tertiary lava pile, being more irregular due to the subglacial volcanic activity. The erupted magma forms pillow lava, pillow breccia, or glassy tuff at the eruptive site,

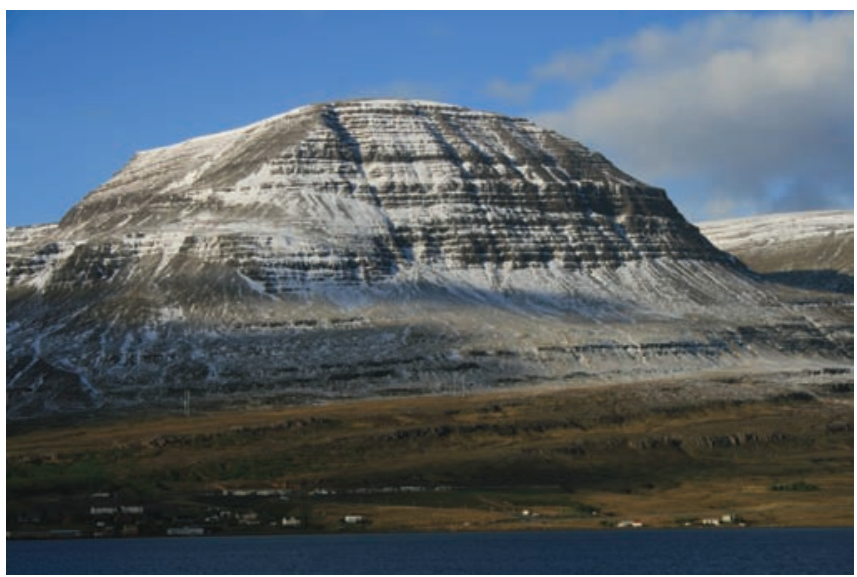

Figure 6 Tertiary lava sequence in Reydarfjördur, Eastern Iceland. Tilt of lava varies from $5-10^{\circ}$ close to sea level to almost zero near the top of the mountain (Photo: Freysteinn Sigmundsson). 
commonly confined by the ice, causing the material to pile up rather than spread. Subaerially erupted lavas are found in between the subglacial formations, indicating that the Plio-Pleistocene was characterized by alternating warm and cold periods, with glaciation recurring every 100,000-130,000 years (Saemundsson and Noll, 1967; Geirsdóttir and Eiríksson 1994; Geirsdóttir et al., 2007). In southwestern Iceland, Kristjansson et al. (1980) found evidence for 13 glaciations between 3.1 and $1.8 \mathrm{Ma}$, in a $2.1 \mathrm{~km}$ thick succession of lavas separated by glacial horizons. Rocks from the Plio-Pleistocene epoch lie conformably above the Tertiary sequence. Exceptions occur on the Skagi peninsula in northern Iceland and on Snæfellsnes in western Iceland, where an unconformity exists between the PlioPleistocene sequence and the Tertiary lava pile. Erosion has cut over $1000 \mathrm{~m}$ deep into the lower part of the Plio-Pleistocene series revealing the same structural features that characterize the Tertiary series.

The boundary between the Plio-Pleistocene and the Upper Pleistocene is set at $0.8 \mathrm{Ma}$, at the reversal from the Matuyama magnetic epoch to the Brunhes magnetic epoch of normal polarity. As a rule the two are separated by a hiatus associated with a wide apron of non-tilted interglacial lavas at the margins of the Upper Pleistocene. The Upper Pleistocene rock series is characterized by more voluminous hyaloclastite formations than the Plio-Pleistocene, in addition to lavas erupted during interglacial times. The rather dominating hyaloclastite landscape features among the subglacially erupted volcanics of the Upper Pleistocence, in particular ridges and tuyas, gave rise to the collective term "Palagonite formation" (Móberg in Icelandic). The increased proportion of subglacially formed rocks relative to subaerially erupted rocks in the Upper Pleistocene indicates more extensive and longer lasting glaciations than earlier. Furthermore, glacial erosional features are in general insignificant in the Upper Pleistocene sequence as volcanic accumulation appears to have dominated over glacial or fluvial erosion (Saemundsson, 1979). In addition to being little eroded, the formations of the Upper Pleistocene can frequently be related to currently active volcanic systems. The Upper Pleistocene rock series, together with postglacially erupted rocks, are referred to as the neovolcanic zone of Iceland. Rocks from the Upper Pleistocene reveal a relationship between subglacial volcanic edifices and the ice sheets in which they formed, such that their height correlates with the ice thickness at the time of formation (Walker, 1965). Various studies (e.g., Walker and Blake 1966; Saemundsson, 1967; Werner et al., 1996) demonstrate that subglacial volcanic formations can be very complex, with superimposed or overlapping eruptive units formed in a number of eruptions under different environmental conditions.

The beginning of Postglacial time is not fixed as deglaciation procceded from the outer parts of Iceland towards the interior over a period of a few thousand years, beginning before the Younger Dryas. Extensive fresh lava flows and pyroclastics as well as sediments and soil formed after deglaciation, and characterize this epoch. Postglacial lavas are glacially uneroded and cover a large part of the neovolcancic zone of Iceland. The most extensive postglacial sediments occur along the south coast of Iceland, formed in repeated glacial outburst floods (jökulhlaup), associated with subglacial volcanic eruptions. Postglacial lavas are divided into prehistorical (older than 1100 years) and historical, a division based on the establishment of the first settlements in the country in the late 9th century. The intensity of volcanism during postglacial time has varied, with much more extensive volcanic production in the first millennia after deglaciation than is occurring now. This applies in particular to the lava shields, of which only two have formed during the last 3000 years; ten times more were erupted during the first three millenia after deglaciation.

\section{The plate boundary and magma movements}

The oldest part of the present-day plate boundary configuration in Iceland dates from 6-7 Ma. At that time a major eastward shift of the plate boundary occurred, leaving synclinal structures in western Iceland, at Snæfellsnes and west of Skagi as evidence of its former position. The shift has been explained as a response to gradual westward drift of the plate boundary away from the central plume upwelling under Iceland, because both Eurasian and North American plates have a westward component of movement in an absolute plate motion model, relative to fixed hot spots (Gripp and Gordon, 2002). Volcanism within the presently active zones on Iceland differs widely in character. Intense volcanism has built up a number of volcanic edifices through repeated eruptions. These foci of volcanic production along the volcanic zones are analogues to the eroded central volcanic complexes in the older series. Most of these central volcanoes are associated with silicic rocks, high-temperature geothermal areas, and many have developed a caldera. Crater rows formed in fissure eruptions, often grouped together with an array of normal faults, transect the central volcanoes. Accordingly, the neovolcanic zone is segmented into a number of volcanic systems (Figure 7). These differ in terms of volcanic production, proportion of silicic rocks, eruption frequency and tectonic character. They also have their own petrographic and geochemical differences which are most pronounced between volcanic systems in the spreading zone and those in the off-rift volcanic zones (Jakobsson, 1979a and b). The strike of the plate boundary varies and most of it is oblique to the spreading direction, causing en echelon arrangement of the volcanic systems. A similar arrangement is found for volcanic systems in the eroded Tertiary lava pile, with dike swarms extending away from central volcanoes into several million years older crust (Walker, 1974). Seismicity is mostly focused in two transform zones, the South-Iceland Seismic Zone and Tjörnes Fracture Zone, that tie the offset Iceland segment of the spreading zones up with the submarine

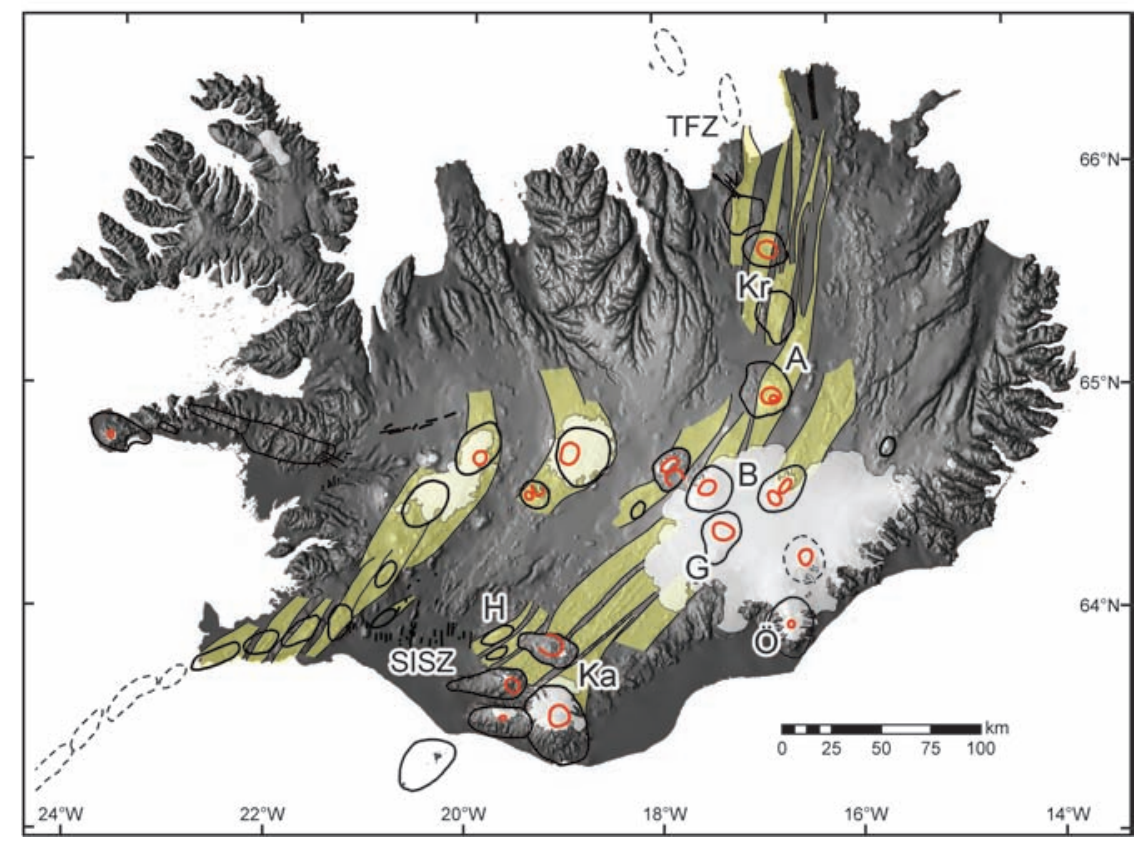

Figure 7 Volcanic systems in Iceland, as mapped by Einarsson and Samundsson (1987). Background map shows shaded topography. The volcanic systems consists of fissure swarms (yellow shading with outlines), central volcanoes (thick oval outlines), and calderas at some of the central volcanoes (red oval outlines). Names of selected volcanic systems are indicated: Askja (A), Bárdarbunga (B), Grímsvötn (G), Hekla $(\mathrm{H})$, Krafla $(\mathrm{Kr})$, Katla $(\mathrm{Ka})$, and Örafajökull $(\ddot{O})$. Locations of the South Iceland Seismic Zone (SISZ) and the Tjörnes Fracture Zone (TFZ) are also shown. 
Reykjanes and Kolbeinsey Ridges. In south Iceland, there are two subparallel spreading zones with different types of volcanism: lava shields of olivine tholeiite in the west and fissure eruptions of tholeiite in the east. There is evidence that the eastern zone formed later and is propagating to the southwest.

Throughout historical time, about 20-25 eruptions have occurred per century, with variable eruption styles (Thordarson and Larsen, 2007). Some of the volcanoes are subglacial (Figure 8) and in these cases, ice-volcano interaction is important (Gudmundsson et al., 1997). Large explosive eruptions include the 1362 eruption of the Mt. Oræfajökull stratovolcano, and a plinian eruption associated with caldera collapse at the Askja volcano in 1875 . The volcanic production varies from one volcano to another, with the Hekla, Katla, Grímsvötn, and the Bárdarbunga volcanoes being the most active. The volumes of erupted products in individual volcano-tectonic episodes in Iceland span more than three orders of magnitude, from being less than 0.2 to c. $20 \mathrm{~km}^{3}$, suggesting that widely different volumes of magma may accumulate in the crust prior to eruption. The largest lava producing eruptions were the Laki eruption in 1783-1784 (in the Grímsvötn volcanic system) and the Eldgjá eruption in c. 934 (in the Katla volcanic system), each with $15 \mathrm{~km}^{3}$ or more of erupted material. The episodic nature of magmatic activity is not only reflected in intermittent volcanic activity; episodic events happen as well deep in the crust. Extensive studies of crustal deformation (e.g., Sigmundsson, 2006; Sturkell et al., 2006) and seismicity have revealed that the flow of magma through the lower crust towards shallow levels is highly episodic, resulting in periods of inflation and measurable ground deformation on the surface of the Earth. Recorded inflation episodes range in time from several months up to 15 years, with cumulative magma volumes ranging from c. 0.001 to $1 \mathrm{~km}^{3}$. Only few of these episodes result in eruptions; often magma is emplaced at depth in the crust without an eruption at the surface (e.g., Pedersen and Sigmundsson, 2006). Between the relatively short periods of inflation, Icelandic volcanoes subside or show no signs of deformation. Because of limited magma inflow, shallow crustal magma chambers, typically at 3-7 km depth, are only found at the most active volcanoes in Iceland.

Various observations provide constraints on the crustal spreading process. The spreading leads to build-up of extensional stress in the uppermost part of the crust at a steady rate, and an associated decompressional melting in the mantle. Stretching across the fissure swarms prior to rifting causes subsidence of the fissure swarms as well. The stress is primarily released in large rifting episodes, when failure occurs on long segments of the plate boundary such as the entire length of a single volcanic system. The time between large rifting episodes is irregular, but on the order of 100 to 1000 years in each location along the plate boundary. The three most recent rifting episodes in the volcanic zone north of the Vatnajökull ice cap

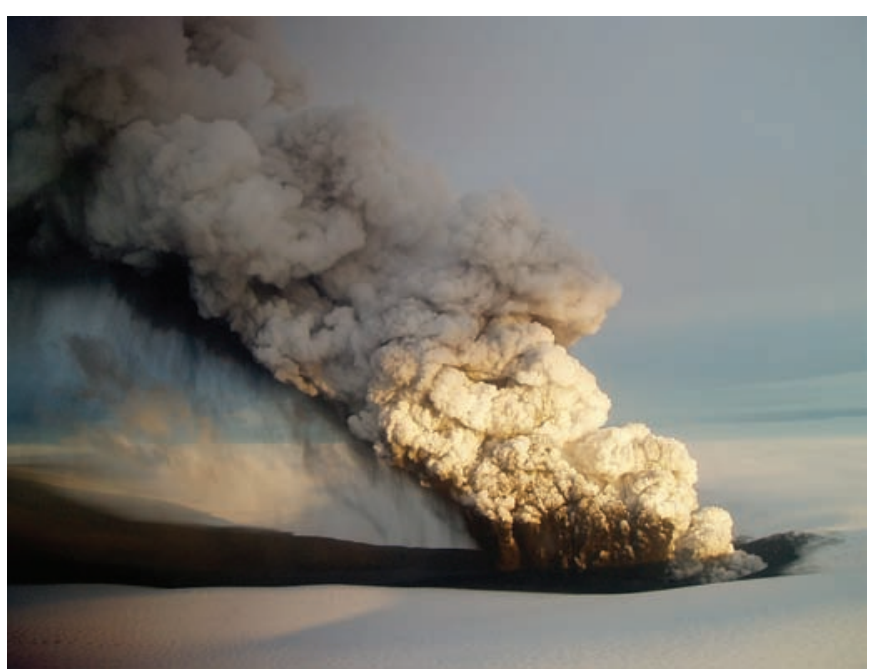

Figure 8 The subglacial eruption of Grímsvötn volcano, Vatnajökull ice cap, in 2004. (Photo: Freysteinn Sigmundsson). occurred in the Krafla volcanic system in 1724-1729, the Askja system in 1874-1875, and in Krafla system again in 1975-1984. The last one is the only one instrumentally recorded. The time intervals between rifting episodes are not only dependent on the amount of stretching since a preceding rifting episode. Availability of magma in the shallow crust appears to be critical, as magma allows "hydraulic fracturing" of crust at much lower stress levels than needed for faulting. The Krafla 1975-1984 rifting episode was associated with continuous inflow of magma towards a 3-7 km deep magma chamber under Krafla (Tryggvason, 1994; Brandsdottir et al., 1997). This was interrupted about twenty times by sudden deflation events when the chamber failed and dikes were expelled, with less than half of them reaching the surface. The $80 \mathrm{~km}$ long Krafla fissure swarm (spreading segment) widened on average by 4-6 metres. Diking events without eruptions were associated with formation of tension fractures and extensive normal faulting above them. Accommodation of plate movements thus appears to occur by different mechanisms throughout the crust. Widening by faulting and formation of tension fractures occurs in the near surface layer, whereas dikes dominate at greater depth. The dikes formed in the Krafla rifting episode have been estimated to extend to less than 10 km depth (Tryggvason, 1984; Árnadóttir et al., 1998), whereas in this location the crust is about $20 \mathrm{~km}$ thick. Ductile deformation mechanisms may be important in accommodating the plate movements in the lower crust.

\section{Conclusions}

The divergent plate boundary in Iceland is complex because of an interplay between a mantle plume under Iceland and the spreading across the Mid-Atlantic ridge. The geology of Iceland reflects a complicated history of rift relocations, as well as variable climatic conditions that have shaped the environment and influenced volcanic activity. A number of tectonic and magmatic processes can be observed in Iceland with multiple techniques and approaches, and studied on different time scales. Volcanic activity is frequent, with variable eruption style. Magma intrusions and diking events associated with formation of the oceanic crust can be studied with modern instrumentation, and these observations can be compared to studies of eroded volcanic structures in the older parts of Iceland that provide a direct view of volcano interiors. All of these features make Iceland a unique "window" on North-Atlantic divergent plate tectonics and geologic processes.

\section{References}

Allen, R.M., Nolet, G., Morgan, W.J., Vogfjord, K., Nettles, M., Ekström, G., Bergsson, B.H., Erlendsson, P., Foulger, G.R., Jakobsdottir, S. Julian, B., Pritchard, M., Ragnarsson, S., and Stefansson, R., 2002, Plume-driven plumbing and crustal formation in Iceland: J. Geophys. Res., 107, doi: 10.1029/2001JB000584.

Árnadóttir, Th., Sigmundsson, F., and Delaney, P.T., 1998, Sources of crustal deformation associated with the Krafla, Iceland, eruption of September 1984: Geophys. Res. Lett., 25, 1043-1046.

Brandsdottir, B., Menke, W., Einarsson, P., White, S., and Staples, R.K., 1997, Faroe-Iceland ridge experiment 2. Crustal structure of the Krafla central volcano: J. Geophys. Res., 102, 7867-7886.

DeMets, C., Gordon, R.G., Argus, D.F., and Stein, S., 1994, Effect of recent revisions to the geomagnetic reversal time scale on estimates of current plate motions: Geophys. Res. Lett., 21, 2191-2194.

Einarsson, P., in press. Plate boundaries, rifts and transforms in Iceland, Jökull: Icelandic Journal of Earth Sciences, Special Issue 2008.

Einarsson, P. and Sæmundsson, K., 1987, Earthquake epicenters 1982-1985 and volcanic systems in Iceland, in: Th. Sigfusson, ed., I hlutarins edli: Festschrift for Thorbjorn Sigurgeirsson, Menningarsjodur, Reykjavik (map).

Eysteinsson, H. and Gunnarsson, K., 1995, Maps of gravity, bathymetry and magnetics for Iceland and surroundings, Orkustofnun, Reykjavik, Rep. OS-95055/JHD-07. 
Geirsdóttir, Á. and Eiríksson J., 1994, Growth of an intermittent ice sheet in Iceland during the late Pliocene and early Pleistocene: Quaternary Research 42, 115-130.

Geirsdóttir, Á., Miller, G.H., and Andrews, J.T., 2007, Glaciation, erosion, and landscape evolution of Iceland: Journal of Geodynamics, 43, $170-186$.

Geirsson, H., Árnadóttir, Th., Völksen, C., Jiang, W., Sturkell, E., Villemin, T., Einarsson, P., Sigmundsson, F., and Stefánsson, R., 2006, Current plate movements across the Mid-Atlantic ridge determined from 5 years of continuous GPS measurements in Iceland: J. Geophys. Res., 111, B09407.

Gripp, A.E. and Gordon, R.G., 2002, Young tracks of hotspots and current plate velocities: Geophys. J. Int., 150, 321-361.

Gudmundsson, Ó., 2003, The dense root of the Iceland crust: Earth and Planetary Science Letters, 206, 427-440.

Gudmundsson, M.T., Sigmundsson, F., and Bjornsson, H., 1997, Ice-volcano interaction of the 1996 Gjálp subglacial eruption, Vatnajökull, Iceland: Nature, 389, 954-957.

Jakobsson, S.P., 1979a, Petrology of recent basalts of the Eastern Volcanic Zone, Iceland: Acta Naturalia Islandica, 26, 1-103.

Jakobsson, S.P., 1979b, Outline of the petrology of Iceland: Jökull, 29, 57-73.

Jóhannesson, H. and Sæmundsson, K., 1998, Geological Map of Iceland, 1:500 000: Bedrock Geology, Icelandic Institute of Natural History

Jonsson, G., Kristjansson, L., and Sverrisson, M., 1991, Magnetic surveys of Iceland: Tectonophysics, 189, 229-247.

Kristjánsson, L., Jónsson, G. and Sverrisson, M., 1989, Magnetic surveys at the Science Institute: Report RH01.89, Science Institute., Univ. of Iceland, 44pp and colour map at a scale 1:1,000,000

Kristjansson, L., Fridleifsson, I.B. and Watkins, N.D., 1980, Stratigraphy and paleomagnetism of the Esja, Eyrarfjall and Akrafjall Mountains: Journal of Geophysics, 47, 31-42.

Maclennan, J., McKenzie, D., and Gronvöld, K., 2001a, Crustal accretion under northern Iceland: Earth and Planetary Science Letters, 191, 295-310.

Maclennan, J., McKenzie, D. and K. Gronvöld, 2001b, Plume-driven upwelling under central Iceland: Earth and Planetary Science Letters, 194, 67-82.

Oskarsson, N., Steinthorsson, S., and Sigvaldason, G.E., 1985, Iceland geochemical anomaly: Origin, volcanotectonics, chemical fractionation and isotope evolution of the crust: J. Geophys. Res., 90, 10011-10255.

Pagli, C., F. Sigmundsson, B. Lund, E. Sturkell, H. Geirsson, P. Einarsson, Th. Árnadóttir, and S. Hreinsdóttir, 2007, Glacio-isostatic deformation around the Vatnajökull ice cap, Iceland, induced by recent climate warming: GPS observations and Finite Element Modeling: J. Geophys. Res., 112, B08405.

Pedersen, R., Sigmundsson, F., 2006, Temporal development of the 1999 intrusive episode in the Eyjafjallajökull volcano, Iceland, derived from InSAR images: Bull. Volc., 68, 377-393.

Sæmundsson, K. , 1967, Vulkanismus und Tektonik des Hengill-Gebietes in Südwest-Island: Acta Naturalia Islandica 2, No.7, 1-105 Hengill-Gebietes, in SW-Island

Sæmundsson, K. and Noll H., 1974, K/Ar ages of rocks from Húsafell, Western Iceland, and the development of the Húsafell central volcano: Jökull $24,40-59$.

Sæmundsson, K., 1974, Evolution of the axial rifting zone in Northern Iceland and the Tjörnes Fracture Zone: Bull. Geol. Soc. Am., 85, 495-504.

Saemundsson, K., 1978, Fissure swarms and central volcanoes of the neovolcanic zones of Iceland, in Bowes, D. R. and Leake, B. E., eds., "Crustal evolution in NW-Britain and adjacent regions: Geol. J. Spec. Issue, 10, 415-432.

Saemundsson, K., 1979, Outline of the geology of Iceland: Jökull, 29, 7-28.

Saemundsson, K., 1986, Subaerial volcanism in the western North Atlantic, in Vogt, P.R., and Tucholke, B.E., eds., The Geology of North America, Volume M, The Western North Atlantic Region: Geological Society of America, 69-86.

Sella, G. F., Dixon, T., Mao, A., 2002, REVEL: A model for recent plate velocities from space geodesy: J. Geophys. Res., 107, doi: 10.1029/ 2000JB00033.

Sigmundsson, F., 2006, Iceland Geodynamics, Crustal Deformation and Divergent Plate Tectonics: Praxis Publishing-Springer Verlag, Chichester, UK, 209 pp

Sturkell, E., Einarsson, P., Sigmundsson, F., Geirsson, H., Olafsson, H., Pedersen, R., E. de Zeeuw-van Dalfsen, Linde, A.L., Sacks, I.S., and Stefansson, R., 2006, Volcano geodesy and magma dynamics in Iceland: J. Volc. Geotherm. Res., 150, 14-34.

Thordarson, T. and Larsen, G., 2007, Volcanism in Iceland in historical time: Volcano types, eruption styles and eruptive history: Journal of Geodynamics, 43, 118-152.
Tryggvason, E., 1984, Widening of the Krafla fissure swarm during the 1975 1981 volcano-tectonic episode: Bull. Volcanol., 47, 47-69.

Tryggvason, E., 1994, Surface deformation at the Krafla volcano, north Iceland: Bull. Volc., 56, 98-107.

Vogt, P.R., Johnson, G.L., and Kristjansson, L., 1980, Morphology and magnetic anomalies north of Iceland: J. Geophys., 47, 67-80.

Walker, G.P.L., 1965, Some aspects of Quaternary volcanism: Trans. Leiscester Lit. Phil. Soc., 59, 25-40.

Walker, G.P.L., 1974, The structure of eastern Icealnd, in: L. Kristjánsson (editor) Geodynamics of Iceland and the North Atlantic Area: Reidel Publishing Company, Dordrecht, Holland, 177-188

Walker, G.P.L. and Blake D.H., 1966, Formation of a palagonite breccia mass beneath a valley glacier in Iceland: Q, J. Geol. Soc. of London 122, 45-61.

Werner, R., Schmincke, H.-U. and Sigvaldason, G., 1996, A new model for the evolution of table mountains: volcanological and petrological evidence from Herdubreid and Herdubreidartögl volcanoes (Iceland): Geol. Rundsch., 85, 390-397.

Freysteinn Sigmundsson is a researcher at the Nordic Volcanological Center, Institute of Earth Sciences, University of Iceland. He has studied crustal deformation in Iceland with a variety of techniques including Global Positioning System geodesy and satellite radar interferometry (InSAR). Various processes have been studied with these techniques, including volcanic and magmatic process, and response of the Earth to variable loads on the surface of the Earth. He is managing the Nordic Volcanological Center, a Nordic center for cooperation and research in volcanology and related fields.

Kristján Samundsson is a geologist, retired since 2006. His professional carrier has been in the field of geothermal research. He was a staff member of the National Energy Authority, and Iceland Geosurvey in Reykjavik, Iceland. He has mapped geology in various parts of Iceland for over 40 years, and is one of the authors of the main geologic map of Iceland. He has published numerous articles and reports, including extensive work on the geologic history and volcanic systems of Iceland.
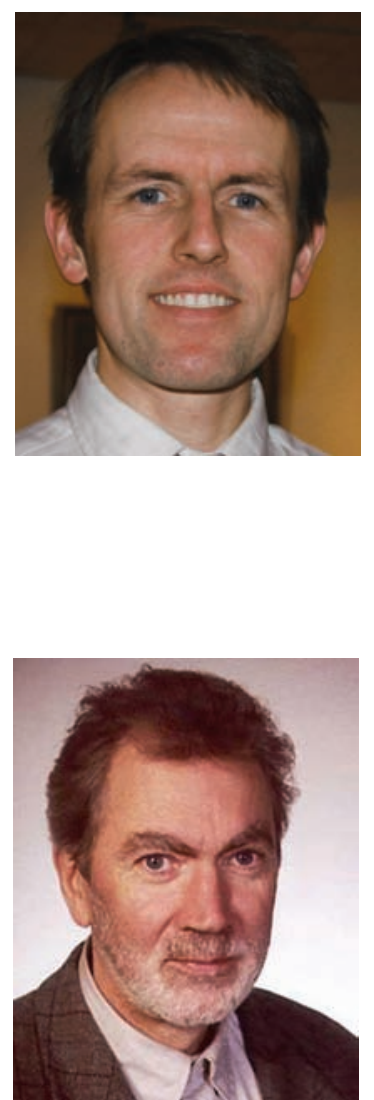